CLINICAL STUDY

\title{
Iodine intake and prevalence of thyroid autoimmunity and autoimmune thyroiditis in children and adolescents aged between 1 and 16 years
}

\author{
Emilio García-García, María Ángeles Vázquez-López, Eduardo García-Fuentes ${ }^{1}$, Firma Isabel Rodríguez-Sánchez ${ }^{2}$, \\ Francisco Javier Muñoz ${ }^{2}$, Antonio Bonillo-Perales and Federico Soriguer ${ }^{1}$ \\ Hospital Torrecárdenas, Unidad de Pediatría, Paraje Torrecárdenas, s/n, E-04009 Almería, Spain, ${ }^{1}$ Hospital Carlos Haya, Unidad de Endocrinología \\ y Nutrición, Málaga, Spain and ${ }^{2}$ Hospital Torrecárdenas, Unidad de Biotecnología, Almería, Spain
}

(Correspondence should be addressed to E García-García; Email: ggej@hotmail.com)

\begin{abstract}
Objectives: To determine the status of iodine nutrition in children and adolescents in Almería, Spain. To calculate prevalence of thyroid autoimmunity (TA) and autoimmune thyroiditis (AT) in pediatric ages and to research into associated factors.

Methods: Cross-sectional epidemiological study. By a multistage probability sampling 1387 children and adolescents aged between 1 and 16 were selected. Physical examination was carried out including neck palpation. Parents were asked about eating habits as well as about social and demographic aspects. Urinary iodine, free thyroxine, TSH, antiperoxidase and antithyroglobulin antibodies were measured. TA was diagnosed when any antibody was positive and AT when autoimmunity was associated with impaired thyroid function or goitre. Results are shown using percentages (and its 95\% confidence interval). To study associated factors we used multiple logistic regression, quantifying the relation with odds ratio (OR), and multiple lineal regression.

Results: Median urinary iodine concentration was $199.5 \mu \mathrm{g} / \mathrm{l}$. The prevalences of TA and AT were $3.7 \%(2.4-5.0)$ and $1.4 \%(0.4-2.4)$. TA is associated with female sex (OR 2.78; $P<0.001)$ and age (OR 1.30; $P<0.001)$. Iodine status is associated with the intake of milk and dairy product $(P<0.001)$ and vegetable $(P=0.021)$ but not with use of iodized salt at home $(P=0.1)$.

Conclusions: The iodine supply in children and adolescents in our city is optimal. Milk and dairy products are the most important iodine sources. TA and AT are prevalent in pediatric ages in our city mainly in females and older subjects.
\end{abstract}

European Journal of Endocrinology 167 387-392

\section{Introduction}

Iodine deficit causes high morbidity in pediatric ages producing psychomotor and growth retardation, goitre and hypothyroidism. To optimize this trace element remains a medical challenge (1). Iodine sufficiency in turn increases the possibilities of suffering from an autoimmune thyroid disease $(2,3,4)$.

Autoimmune thyroiditis (AT) is a destruction of the thyroid gland mediated by lymphocytes and cytokines. Its aetiology shows the importance of predisposing genetic factors as proved by the fact that a third of cases had a family history of autoimmune thyroid diseases and also by the finding of genes that predispose the subjects to them $(5,6)$. However, the onset of the disease must be triggered by environmental factors, especially iodine supply $(2,3,4)$. The iodination of thyroglobulin (TG) stimulates the production of antibodies and the proliferation of lymphocytes, which are its pathogenic bases (7). We know that the prevalence of AT increases exponentially decades after supplying iodine in previously deficient areas $(8,9)$ and also that areas with good iodine supply present prevalences between three and five times higher than those found in deficient areas of the same region $(10,11)$.

No study has estimated the prevalence of autoimmune thyroid disorders in children and adolescents living in Spain. Our study aims to describe iodine intake among children and adolescents in our city, to calculate the prevalence of thyroid autoimmunity (TA) and AT in pediatric ages and to analyze the variables associated with iodine status and with the presence of autoimmune thyroid disease.

\section{Materials and methods}

We conducted an observational cross-sectional epidemiological study on a population sample. The study was focused on the city of Almería and the subjects were 
residents aged between 1 and 16. Almería is a city on the Spanish south coast comprising $\sim 180000$ inhabitants.

Accessible population was obtained from two sources: the Medical District and the Education Office. Data from children aged from 1 to 4 were obtained from the list given by the Medical District of Almería in which all children living in the city are registered for screening for hypothyroidism and phenylketonuria. It virtually coincides with the target population. The district has nine community health centres; 5453 children constitute the cohort of children born between January 2003 and December 2004. Subjects older than 4 correspond to the total number of students registered in November 2004 in the 44 state schools, 26 statesubsidised and private schools of Nursery (4-5 years old) and Primary (6-12 years old) education as well as in the 18 state schools and ten state-subsidised and private schools of Secondary education (12-16 years old) in our city. A total of 17934 children between 4 and 12 years of age and 9823 aged between 12 and 16 were eligible.

A multistage probabilistic sampling was carried out. The primary units were the community health centres of the Medical District and the schools of Nursery, Primary and Secondary education. We randomly selected four community health centres, six schools of Nursery and Primary education (four state and two private) and six schools of Secondary education (four state and two private). Afterwards, three groups of every academic level were selected and all the students in the abovementioned groups were asked to take part in the study.

Assuming a TA prevalence of $10 \%$, a $95 \%$ confidence interval and a precision of $3 \%$, the minimum sampling size needed was 359 individuals aged between 1 and 6 , 376 between 6 and 12, and 370 between 12 and 16 . We selected 550 individuals in each age group in case any of them refused to take part in the study.

Inclusion criteria were that the participants were residents of Almería and aged between 1 and 16 years. Anybody suffering from any endocrine or systemic disease was excluded.

Anthropometric and physical examination data were obtained for each individual. We looked for signs of pubertal development (testicular volume of at least $4 \mathrm{ml}$ in males and breast development in females) and presence of goitre according to the international criteria (12).

Parents were questioned about the following sociodemographic variables: origin (Spanish or immigrant and if so of what origin); socio-economic and cultural: employment situation (employed, unemployed, retired/ disabled, housewife or student); education level (no education, primary or vocational, secondary or university); eating habits: frequency of fruit, vegetables, milk and dairy products, meat, fish, eggs and legumes intake, and how often they eat unnecessary foods, such as baked goods, sweets and snacks; type of salt (iodated or not) and type of oil consumed at home.
Samples of total blood and a urine specimen were collected. Serum free thyroxine (normal range 0.9$1.7 \mathrm{ng} / \mathrm{dl}$ ), serum TSH (normal range $0.2-4.2 \mathrm{mU} / \mathrm{l}$ ), antiperoxidase antibodies (TPO ab) (normal value $<34 \mathrm{U} / \mathrm{ml}$ ) and anti-TG antibodies (TG ab; normal value $<115 \mathrm{U} / \mathrm{ml}$ ) were assayed by electrochemiluminescence immunoanalysis (Roche Diagnostics).

Urinary excretion of iodine was assayed by Benotti method (13) in a sample of urine and expressed as micrograms of iodine per litre of urine. Epidemiologic criteria for assessing iodine nutrition based on median urinary iodine concentrations of school-age children and adults are: iodine deficiency, $<100 \mu \mathrm{g} / \mathrm{l}$; adequate iodine nutrition, $100-199 \mu \mathrm{g} / \mathrm{l}$; above requirements, 200-299 $\mu \mathrm{g} / \mathrm{l}$; and excessive, $>300 \mu \mathrm{g} / \mathrm{l}$ (12).

Table 1 Characteristics of study participants.

\begin{tabular}{|c|c|c|c|}
\hline Variable & $\begin{array}{l}\text { Percentage } \\
\qquad(95 \% \mathrm{Cl})\end{array}$ & $\begin{array}{c}\text { Mean } \\
(95 \% \mathrm{Cl})\end{array}$ & S.D. \\
\hline \multicolumn{4}{|l|}{ Sex } \\
\hline Females & $48.8(46.2-51.4)$ & & \\
\hline Males & $51.2(48.6-53.8)$ & & \\
\hline Age (years) & & $8.37(8.13-8.61)$ & 4.5 \\
\hline \multicolumn{4}{|l|}{ Pubertal status } \\
\hline Prepubertal & $63.6(62.4-64.8)$ & & \\
\hline Pubertal & $36.4(35.4-37.4)$ & & \\
\hline BMI $\left(\mathrm{kg} / \mathrm{m}^{2}\right)$ & & $18.7(18.5-18.9)$ & 3.9 \\
\hline \multicolumn{4}{|l|}{ Ethnicity } \\
\hline Spanish & $89.7(88.1-91.3)$ & & \\
\hline Maghribian & $4.4(3.4-5.4)$ & & \\
\hline Latin American & $4.4(3.4-5.4)$ & & \\
\hline Other & $1.5(0.9-2.1)$ & & \\
\hline \multicolumn{4}{|c|}{ Father's employment situation } \\
\hline Employed & $87.7(86.0-89.3)$ & & \\
\hline Unemployed/retired & $12.3(10.6-14.0)$ & & \\
\hline \multicolumn{4}{|c|}{ Mother's employment situation } \\
\hline Employed & $65.8(63.3-68.3)$ & & \\
\hline Unemployed/housewife & $34.2(31.7-36.7)$ & & \\
\hline \multicolumn{4}{|l|}{ Father's education level } \\
\hline No education & $4.2(3.1-5.3)$ & & \\
\hline Primary & $43.0(40.4-45.6)$ & & \\
\hline Higher & $52.8(50.2-55.4)$ & & \\
\hline \multicolumn{4}{|l|}{ Mother's education level } \\
\hline No education & $3.1(2.2-4.0)$ & & \\
\hline Primary & $40.0(37.4-42.6)$ & & \\
\hline Higher & $56.9(54.3-59.5)$ & & \\
\hline \multicolumn{4}{|l|}{ How often they consume } \\
\hline Fruit (per day) & & $0.82(0.78-0.85)$ & 0.58 \\
\hline Vegetables (per day) & & $0.73(0.70-0.76)$ & 0.44 \\
\hline $\begin{array}{l}\text { Milk and dairy products } \\
\text { (l/day) }\end{array}$ & & $0.67(0.65-0.69)$ & 0.25 \\
\hline Meat (per week) & & 4.07 (3.95-4.20) & 1.88 \\
\hline Fish (per week) & & $2.86(2.76-2.95)$ & 1.38 \\
\hline Eggs (per week) & & $2.36(2.28-2.45)$ & 1.28 \\
\hline Pulses (per week) & & $2.89(2.79-3.00)$ & 1.53 \\
\hline Baked goods (per week) & & $2.19(2.00-2.38)$ & 2.80 \\
\hline Sweets (per week) & & $2.19(1.93-2.44)$ & 3.74 \\
\hline Snacks (per week) & & $1.71(1.52-1.89)$ & 2.51 \\
\hline $\begin{array}{l}\text { Type of oil consumed: } \\
\text { olive }\end{array}$ & $89.2(87.6-90.8)$ & & \\
\hline $\begin{array}{l}\text { Type of salt consumed: } \\
\text { iodized }\end{array}$ & $47.3(46.4-48.2)$ & & \\
\hline
\end{tabular}

$95 \% \mathrm{Cl}, 95 \%$ confidence interval. 
Concentrations above $500 \mu \mathrm{g} / \mathrm{l}$ were regarded as contamination.

TA was diagnosed when any thyroid antibody was positive and AT when TA were associated with impaired thyroid function (TSH values above $4.2 \mathrm{mU} / \mathrm{l}$ or below $0.2 \mathrm{mU} / \mathrm{l})$ or goitre.

Fieldwork was carried out from September 2007 to June 2010. Those in charge of questioning and examining individuals were physicians who followed a programme of training and criteria standardization. Consistency among criteria was assessed by obtaining a consistency coefficient of 0.90 .

Software Statistical Package for Social Sciences (SPSS Inc., Chicago, IL, USA) 17.0 for Windows was used to conduct the statistical analysis and Epidat 3.0 was used for the sample size calculation. In descriptive statistics qualitative variable results are expressed in percentages and 95\% confidence intervals (95\% CIs) and quantitative variables are expressed in mean $(95 \%$ CI $) \pm$ s.D. To study the relation between TA (dichotomous dependent variable) and independent variables, we used binary and multiple logistic regressions quantifying the relation with odds ratio (OR $(95 \% \mathrm{CI})$ ). To study the relation between urinary excretion of iodine (continuous dependent variable) and independent variables, we used binary and multiple lineal regressions. $P<0.05$ was considered to have statistical significance.

The study was approved by the Research and Ethical Committees of Torrecárdenas Hospital.

Written informed consent from the parents or tutors and the individuals themselves (if they were older than 12) was obtained after full explanation of the purpose and nature of all procedures used.

\section{Results}

A total of 1387 children and adolescents enrolled in the study (478 aged between 1 and 6,505 between 6 and 12 , and 404 between 12 and 16).

A description of the samples is given in Table 1 . Our city has received a high number of immigrants in recent years $(10.3 \%$ of children have a foreign origin, mainly Maghribian and Latin American). The rate of unemployment is high (only $87.7 \%$ of fathers and $65.8 \%$ of mothers state that they are employed), and the rate of parents with no education is $4.2 \%$ of fathers and $3.1 \%$ of mothers. Regarding eating habits, fruit, vegetables, fish, eggs and pulses intake is not sufficient but our children and adolescents eat enough dairy products and too much unnecessary food (baked goods, sweets and snacks). In $47.3 \%$ of families iodized salt was used.

The urinary iodine concentration was 209.1 $( \pm 101.4) \mu \mathrm{g} / \mathrm{l}$ (median $199.5 \mu \mathrm{g} / \mathrm{l})$. Of the probands, $15.2 \%$ had a concentration below $100 \mu \mathrm{g} / \mathrm{l}$ indicating iodine deficiency and $19.9 \%$ were above $300 \mu \mathrm{g} / \mathrm{l}$ indicating excess (Table 2). Iodine status is associated
Table 2 Clinical and laboratory findings of study participants.

\begin{tabular}{|c|c|c|c|}
\hline Variable & $\begin{array}{l}\text { Percentage } \\
(95 \% \mathrm{Cl})\end{array}$ & $\begin{array}{c}\text { Mean } \\
(95 \% \mathrm{Cl})\end{array}$ & S.D. \\
\hline Goitre & $4.8(3.4-6.2)$ & & \\
\hline la & $3.4(2.4-4.4)$ & & \\
\hline $\mathrm{lb}$ & $1.1(0.6-1.6)$ & & \\
\hline II & $0.3(0.0-1.2)$ & & \\
\hline TSH (mU/l) & & $2.79(2.71-2.87)$ & 1.48 \\
\hline Free thyroxine (ng/dl) & & $1.32(1.30-1.33)$ & 0.22 \\
\hline Hyperthyroidism & $0.6(0.0-1.8)$ & & \\
\hline Hypothyroidism & $0.2(0.0-0.8)$ & & \\
\hline $\begin{array}{l}\text { Antiperoxidase } \\
\text { antibodies (U/ml) }\end{array}$ & & $10.31(8.62-12.00)$ & 32.1 \\
\hline $\begin{array}{l}\text { Antiperoxidase } \\
\text { antibodies }+\end{array}$ & $2.1(1.6-2.6)$ & & \\
\hline $\begin{array}{l}\text { Antithyroglobulin } \\
\text { antibodies (U/ml) }\end{array}$ & & $31.94(23.09-40.78)$ & 167.9 \\
\hline $\begin{array}{l}\text { Antithyroglobulin } \\
\text { antibodies }+\end{array}$ & $3.0(2.1-3.9)$ & & \\
\hline Thyroid autoimmunity & $3.7(2.4-5.0)$ & & \\
\hline $\begin{array}{l}\text { Isolated thyroid } \\
\text { antibodies }\end{array}$ & $2.3(1.4-3.2)$ & & \\
\hline Autoimmune thyroiditis & $1.4(0.4-2.4)$ & & \\
\hline Simple goitre (without ab) & $3.7(2.4-5.0)$ & & \\
\hline $\begin{array}{l}\text { Urinary iodine excretion } \\
(\mu \mathrm{g} / \mathrm{l})\end{array}$ & & $209.1(203.0-215.3)$ & 101.4 \\
\hline$<100$ & $15.2(14.5-15.9)$ & & \\
\hline $50-100$ & $12.1(11.6-12.6)$ & & \\
\hline $20-50$ & $2.4(1.4-3.4)$ & & \\
\hline$<20$ & $0.7(0.0-2.0)$ & & \\
\hline $100-200$ & $35.1(34.6-35.6)$ & & \\
\hline $200-300$ & $29.8(28.4-31.2)$ & & \\
\hline$>300$ & $19.9(18.4-21.4)$ & & \\
\hline
\end{tabular}

$95 \% \mathrm{Cl}, 95 \%$ confidence interval.

with the intake of milk and dairy products $(\mathrm{ml} / \mathrm{day}$; adjusted $\beta$ 0.06; $P<0.001$ ) and vegetables (times a day; adjusted $\beta$ 20.7; $P=0.021$ ), but not with use of iodized salt at home (adjusted $\beta$ 13.6; $P=0.10$ ). Urinary iodine was as good in those who do not use iodized salt $(208.8 \pm 101.3 \mu \mathrm{g} / \mathrm{l})$ as in those who use it $(222.4$ $\pm 101.4 \mu \mathrm{g} / \mathrm{l})$.

The serum concentrations of thyroid hormones are shown in Table 2. In 5.0\% of the probands the TSH concentration was $>4.2 \mathrm{mU} / \mathrm{l}$. A clear indication for hypothyroidism with a concentration $>10 \mathrm{mU} / \mathrm{l}$ was found in only $0.2 \%$ and for hyperthyroidism with a concentration $<0.2 \mathrm{mU} / \mathrm{l}$ in $0.6 \%$. Goitre was diagnosed in $4.8 \%$.

The prevalence of TA and AT is shown in Table 2. TA was found in $3.7 \%$ of children and adolescents: TPO ab was found in $2.3 \%$ and TG ab in $3.0 \%$. Thus, the frequency of AT in the study population defined by positive antibodies combined with goitre or abnormal TSH concentration was $1.4 \%$ and isolated TA was $2.3 \%$. Prevalence of goitre and abnormal thyroid function is higher in subjects with TA (Table 3).

Table 4 shows TA and AT prevalence and its 95\% CI for each age, sex, pubertal status and iodine intake groups. In females the prevalence was higher than in males $(P<0.001)$. Female preponderance was also found in prepubertal children $(P=0.03)$. There were 
Table 3 Prevalence of goitre and abnormal thyroid function in subjects with and without thyroid autoimmunity and in different iodine intake groups.

\begin{tabular}{|c|c|c|c|c|}
\hline & Goitre & $\begin{array}{c}\mathrm{TSH}<0.2 \\
\mu \mathrm{U} / \mathrm{ml}\end{array}$ & $\begin{array}{c}\mathrm{TSH}>4.2 \\
\mu \mathrm{U} / \mathrm{ml}\end{array}$ & $\begin{array}{c}\mathrm{TSH}>10 \\
\mu \mathrm{U} / \mathrm{ml}\end{array}$ \\
\hline \multicolumn{5}{|c|}{ Thyroid autoimmunity } \\
\hline Positive (\%) & 25.5 & 5.9 & 3.9 & 5.9 \\
\hline Negative (\%) & 4.0 & 0.4 & 4.8 & 0.0 \\
\hline$P$ value & $<0.001$ & $<0.001$ & 0.70 & $<0.001$ \\
\hline \multicolumn{5}{|l|}{ lodine intake } \\
\hline Deficient & 6.2 & 0.0 & 2.5 & 0.0 \\
\hline Adequate & 3.9 & 1.3 & 4.3 & 0.0 \\
\hline $\begin{array}{l}\text { Above } \\
\text { requirements }\end{array}$ & 3.3 & 0.6 & 6.4 & 0.6 \\
\hline Excessive & 3.8 & 0.0 & 6.2 & 0.5 \\
\hline$P$ value & 0.26 & 0.36 & 0.36 & 0.36 \\
\hline
\end{tabular}

differences among age groups as well. The highest prevalence is found in the group of individuals aged between 12 and 16 and the lowest in the group aged between 1 and $6(P<0.001)$, and between pubertal vs prepubertal subjects $(P<0.001)$. Differences in TA and AT prevalence between iodine intake groups did not reach statistical significance.

Variables related to TA were female sex (OR 2.78 (1.89-5.28); $P<0.001)$ and age (OR 1.30 (1.15-1.46); $P<0.001)$.

\section{Discussion}

Children and adolescents of Almería have a sufficient intake of iodine as shown by the median urinary iodine excretion (UIE) and goitre prevalence. The studies on children and adolescents in Andalusia, our region, published up to now have shown high goitre prevalence (between 19 and 37\%), which is associated with an insufficient intake of this trace element, whereas median UIE were low within acceptable levels, between 109 and $130 \mu \mathrm{g} / \mathrm{l}(14,15,16)$. However, recent papers studying other Spanish regions showed an optimal iodine intake with median UIE between 150 and $200 \mu \mathrm{g} / \mathrm{l}$ in children older than $6(17,18)$, as well as in children younger than 6 and infants $(19,20)$, although iodized salt had not become widespread in any of the regions.

In many areas, the intake of dairy products was proved to be strongly associated with iodine supply $(21,22,23,24)$ and this has been the case in our region $(15,16)$ too. Milk and dairy products are an important source of iodine; in fact, they now have a higher amount of iodine $(25,26)$. An analysis of 45 brands of milk in Spain showed that the concentration of this trace element has doubled now $(259 \mu \mathrm{g} / \mathrm{l}$ on average) compared with 20 years ago. As a result, if children take the recommended half a litre of dairy products a day, they will have a sufficient iodine supply (26).

With regard to the frequency of autoimmune thyroid disorders, as it is directly proportional to age and iodine intake of the population, very different data can be found in published papers. The prevalence of TA in adults is around $10-13 \%$ and that of AT is $3-5 \%$ (in the elderly it goes up to $9.5 \%)(2,3,4)$. The only data from Spain available show a prevalence of TG ab of $9.7 \%$ and TPO ab of $3.4 \%$ (27) in a sample of 400 individuals including adults and children older than 6 with a median UIE of $120 \mu \mathrm{g} / \mathrm{l}$.

Despite the few data on prevalence in paediatric ages, we know that it is higher among adolescents although this pathology can appear even in children younger than $2(2,3,4)$. In regions with an optimal iodine supply, prevalence of AT ranges between $2.5 \%$ and $3.6 \%$ in Greece (28), 2.6\% in India (29), 2.9\% in Sardinia (30), 3.0\% in Berlin (31) and 3.6\% in Turkey (32). These results are similar to ours as they include only children older than 6 . In regions where the median UIE reaches $200 \mu \mathrm{g} / \mathrm{l}$, prevalences are very high, for example, $5.1 \%$ in Sweden (33) and $9.6 \%$ in the north west of Greece (9); even in these two studies all children were older than 12.

The consequences that an excess of iodine may entail for our health are less well known than those produced by a deficit. A recent study in China associated excess of iodine with intellectual deficit as it showed that students with a median UIE of $228 \mu \mathrm{g} / \mathrm{l}$ due to the consumption of water with a high concentration of iodine have an intellectual quotient nine points lower than average. However, authors do not know whether this fact is mediated by the induction of autoimmune thyroid disease (34).

Children and adolescents of Almería have an optimal iodine supply. The main source of this trace element in their diet is not salt but dairy products. Among children and adolescents, autoimmune thyroid disease is very prevalent, especially after the onset of puberty. Our study shows limitations in its design that prevent us from comparing different socioeconomic strata or ethnic

Table 4 Prevalence (\% and $95 \% \mathrm{Cl}$ ) of thyroid autoimmunity, and autoimmune thyroiditis in individuals aged 1-16, in each group of age, sex, pubertal status and iodine intake.

\begin{tabular}{llc}
\hline & $\begin{array}{c}\text { Thyroid } \\
\text { autoimmunity }\end{array}$ & $\begin{array}{c}\text { Autoimmune } \\
\text { thyroiditis }\end{array}$ \\
\hline Total group & $3.7(2.4-5.0)$ & $1.4(0.4-2.4)$ \\
Males & $2.3(1.1-3.5)$ & $0.8(0.0-2.8)$ \\
Females & $5.0(3.4-6.6)$ & $1.9(0.9-2.9)$ \\
Prepubertal & $2.4(1.2-3.6)$ & $0.5(0.0-1.8)$ \\
Males & $1.5(0.2-2.8)$ & $0.0(0.0-0.6)$ \\
Females & $3.3(2.3-4.3)$ & $0.9(0.3-1.5)$ \\
Pubertal & $6.8(4.2-9.4)$ & $3.0(1.4-4.6)$ \\
Males & $3.9(1.4-6.3)$ & $2.4(1.1-3.7)$ \\
Females & $8.1(5.8-10.4)$ & $3.6(1.6-5.6)$ \\
12-16 years old & $6.2(4.9-7.5)$ & $3.2(0.0-6.5)$ \\
6-12 years old & $4.6(2.6-6.6)$ & $1.2(0.0-2.4)$ \\
1-6 years old & $0.6(0.0-2.6)$ & $0.0(0.0-0.9)$ \\
lodine intake & & \\
Deficient & $2.6(1.3-5.1)$ & $1.3(0.0-4.5)$ \\
Adequate & $2.9(1.3-6.3)$ & $1.3(0.1-3.1)$ \\
Above requirements & $4.6(2.9-7.8)$ & $1.6(0.1-3.7)$ \\
Excessive & $5.0(2.6-9.6)$ & $1.4(0.0-4.1)$ \\
\hline
\end{tabular}


minorities. It would be interesting to design these studies to identify subpopulations with a deficiency and those with an excessive supply and to create different action plans for each of them.

\section{Declaration of interest}

The authors declare that there is no conflict of interest that could be perceived as prejudicing the impartiality of the research reported.

\section{Funding}

This research did not receive any specific grant from any funding agency in the public, commercial or not-for-profit sector.

\section{References}

1 Zimmermann MB. The adverse effects of mild-to-moderate iodine deficiency during pregnancy and childhood: a review. Thyroid 20077 829-835. (doi:10.1089/thy.2007.0108)

2 Lorini R, Gastaldi R, Traggiai C \& Perucchin PP. Hashimoto's thyroiditis. Pediatric Endocrinology Reviews 20031 (Suppl 2) 205-211.

3 Gopalakrishan S \& Marwaha RK. Juvenile autoimmune thyroiditis. Journal of Pediatric Endocrinology \& Metabolism 200720 961-970. (doi:10.1515/JPEM.2007.20.9.961)

4 Fava A, Oliverio R, Giuliano S, Parlato G, Michniewicz A, Indrieri A, Gregnuoli A \& Belfiore A. Clinical evolution of autoimmune thyroiditis in children and adolescents. Thyroid 200919 361-367. (doi:10.1089/thy.2008.0239)

5 Jacobson EM \& Tomer Y. The CD40, CTLA-4, thyroglobulin, TSH receptor, and PTPN22 gene quintet and its contribution to thyroid autoimmunity: back to the future. Journal of Autoimmunity 2007 28 85-98. (doi:10.1016/j.jaut.2007.02.006)

6 Ban Y \& Tomer Y. Genetic susceptibility in thyroid autoimmunity. Pediatric Endocrinology Reviews 20053 20-32.

7 Rose NR, Rasooly L, Saboori AM \& Burek CL. Linking iodine with autoimmune thyroiditis. Environmental Health Perspectives 1999 107 (Suppl 5) 749-752. (doi:10.1289/ehp.99107s5749)

8 Camargo RY, Tomimori EK, Neves SC, Knobel M \& MedeirosNeto G. Prevalence of chronic autoimmune thyroiditis in the urban area neighboring a petrochemical complex and a control area in Sao Paulo, Brazil. Clinics 200661 307-312. (doi:10. 1590/S1807-59322006000400006)

9 Zois C, Stavrou I, Kalogera C, Svarna E, Dimoliatis I, Seferiadis K \& Tsatsoulis A. High prevalence of autoimmune thyroiditis in schoolchildren after elimination of iodine deficiency in northwestern Greece. Thyroid 200313 485-489. (doi:10.1089/ 105072503322021151)

10 Bastemir M, Emral R, Erdogan G \& Gullu S. High prevalence of thyroid dysfunction and autoimmune thyroiditis in adolescents after elimination of iodine deficiency in the eastern Black Sea region of Turkey. Thyroid 200616 1265-1271. (doi:10.1089/thy. 2006.16.1265)

11 Teng W, Shan Z, Teng X, Guan H, Li Y, Teng D, Jin Y, Yu X, Fan C, Chong W, Yang F, Dai H, Yu Y, Li J, Chen Y, Zhao D, Shi X, Hu F, Mao J, Gu X, Yang R, Tong Y, Wang W, Gao T \& Li C. Effect of iodine intake on thyroid diseases in China. New England Journal of Medicine 2006354 2783-2793. (doi:10.1056/NEJMoa054022)

12 World Health Organization, United Nations Children's Fund, and International Council for the Control of Iodine Deficiency Disorders. Assessment of Iodine Deficiency Disorders and Monitoring their Elimination. A Guide for Programme Managers, 3rd edn. Geneva: World Health Organization, 2007.

13 Benotti J \& Benotti N. Protein bound iodine, total iodine and protein and butanol extractable iodine by partial automation. Clinical Chemistry 196312 408-416.
14 Madueño Caro AJ, Cabezas Saura PB, Díaz Orta J, Benítez Rodríguez E, Ruiz Galdon M \& Gómez A. Prevalence of goitre and iodine deficiency in a school population from a traditionally endemic health area. Atención Primaria 200127 258-262.

15 Soriguer F, Millon MC, Muñoz R, Mancha I, López Siguero JP, Martinez Aedo MJ, Gómez-Huelga R, Garriga MJ, Rojo-Martinez G, Esteva I \& Tinahones FJ. The auditory threshold in a school-age population is related to iodine intake and thyroid function. Thyroid 200010 991-999. (doi:10.1089/thy.2000.10.991)

16 Santiago-Fernandez P, Torres-Barahona R, Muela-Martínez JA, Rojo-Martínez G, García-Fuentes E, Garriga MJ, León AG \& Soriguer F. Intelligence quotient and iodine intake: a crosssectional study in children. Journal of Clinical Endocrinology and Metabolism 200489 3851-3857. (doi:10.1210/jc.2003031652)

17 Peris Roig B, Atienzar Herráez N, Merchante Alfaro AA, Calvo Rigual F, Tenías Burillo JM, Selfa Moreno S \& López García MJ. Endemic goiter and iodine deficiency: are they still a reality in Spain. Anales de Pediatría 200665 234-240. (doi:10.1157/ 13092160)

18 Zubiaur Cantalapiedra A, Zapico Alvarez-Cascos MD, Ruiz Pérez L, Sanguino López L, Sánchez Serrano FJ, Alfayate Guerra R, Sánchez-Paya J, Guirao Carratalá MD, Pico Alfonso A \& Flores Serrano J. Iodine nutritional status in the school-aged population in Alicante (Spain). Anales de Pediatría 200766 260-266. (doi:10. 1157/13099688)

19 Díaz-Cadórniga FJ \& Delgado-Álvarez E. Clinical and therapeutic implications of iodine deficiency in Spain. Endocrinología $y$ Nutrición 200653 101-112. (doi:10.1016/S1575-0922 (06)71076-2)

20 Serra-Prat M, Díaz E, Verde Y, Gost J, Serra ME \& Puig Domingo M. Prevalence of iodine deficiency and related factors in 4 year-old schoolchildren. Medicina Cĺnica 2003120 246-249. (doi:10. 1157/13043780)

21 Girelli ME, Coin P, Mian C, Nacamulli D, Zambonin L, Piccolo M, Vianello-Dri A, Gottardo F \& Busnardo B. Milk represents an important source of iodine in schoolchildren of the Veneto region, Italy. Journal of Endocrinological Investigation 200427 709-713.

22 Pearce EN, Pino S, He X, Bazrafshan HR, Lee SL \& Braverman LE. Sources of dietary iodine: bread, cows' milk, and infant formula in the Boston area. Journal of Clinical Endocrinology and Metabolism 200489 3421-3424. (doi:10.1210/jc.2003-032002)

23 Rasmussen LB, Ovesen L, Bülow I, Jørgensen T, Knudsen N, Laurberg P \& Pertild H. Dietary iodine intake and urinary iodine excretion in a Danish population: effect of geography, supplements and food choice. British Journal of Nutrition 200287 61-69. (doi:10.1079/BJN2001474)

24 Jahreis G, Hausmann W, Kiessling G, Franke K \& Leiterer M. Bioavailability of iodine from normal diets rich in dairy products results of balance studies in women. Experimental and Clinical Endocrinology \& Diabetes 2001109 163-167. (doi:10.1055/ s-2001-14840)

25 Bader N, Möller U, Leiterer M, Franke K \& Jahreis G. Pilot study: tendency of increasing iodine content in human milk and cow's milk. Experimental and Clinical Endocrinology E Diabetes 2005113 8-12. (doi:10.1055/s-2004-830508)

26 Soriguer F, Gutierrez-Repiso C, Gonzalez-Romero S, Olveira G, Garriga MJ, Velasco I, Santiago P, de Escobar GM \& GarcíaFuentes E. Iodine concentration in cow's milk and its relation with urinary iodine concentrations in the population. Clinical Nutrition 201130 44-48. (doi:10.1016/j.clnu.2010.07.001)

27 Serna Arnaiz MC, Serra Majem L, Gascó Eguiluz E, Peremiquel Lluch M, Vila Ballester L \& Ibarz Excuer M. The prevalence of antithyroid antibodies in Lleida. Anales de Medicina Interna 2000 17 62-66.

28 Kaloumenou I, Mastorakos G, Alevizaki M, Duntas LH, Mantzou E, Ladopoulos C, Antoniou A, Chiotis D, Papassotiriou I, Chrousos GP \& Dacou-Voutetakis C. Thyroid autoimmunity in schoolchildren in an area with long-standing iodine sufficiency: 
correlation with gender, pubertal stage, and maternal thyroid autoimmunity. Thyroid $2008 \mathbf{1 8}$ 747-754. (doi:10.1089/thy. 2007.0370)

29 Gopalakrishan S, Singh SP, Prasad WR, Jain SK, Ambardar VK \& Sankar R. Prevalence of goitre and autoimmune thyroiditis in schoolchildren in Delhi, India, after two decades of salt iodination. Journal of Pediatric Endocrinology \& Metabolism 200619 889-893. (doi:10.1515/JPEM.2006.19.7.889)

30 Loviselli A, Velluzzi F, Mossa P, Cambosu MA, Secci G, Atzeni F, Taberlet A, Balestrieri A, Martino E, Grasso L, Songini M, Bottazzo GF, Mariotti S \& Sardinian Schoolchildren Study Group. The Sardinian Autoimmunity Study: 3. Studies on circulating antithyroid antibodies in Sardinian schoolchildren: relationship to goiter prevalence and thyroid function. Thyroid $2001 \mathbf{1 1}$ 849-857. (doi:10.1089/105072501316973109)

31 Kabelitz M, Liesenkotter KP, Stach B, Willgerodt H, Stablein W, Singendonk W, Jäger-Roman E, Litzenbörger H, Ehnert B \& Grüters A. The prevalence of anti-thyroid peroxidase antibodies and autoimmune thyroiditis in children and adolescents in an iodine replete area. European Journal of Endocrinology $2003 \mathbf{1 4 8}$ 301-307. (doi:10.1530/eje.0.1480301)
32 Doğan M, Acikgoz E, Acikgoz M, Cesur Y, Ariyuca S \& Bektas MS. The frequency of Hashimoto thyroiditis in children and the relationship between urinary iodine level and Hashimoto thyroiditis. Journal of Pediatric Endocrinology \& Metabolism 2011 24 75-80. (doi:10.1515/jpem.2011.115)

33 Milakovic M, Berg G, Eggertsen R, Lindstedt G \& Nyström E. Screening for thyroid disease of 15-17-year-old schoolchildren in an area with normal iodine intake. Journal of Internal Medicine 2001250 208-212. (doi:10.1046/j.1365-2796. 2001.00878.x)

34 Liu HL, Lam LT, Zeng Q, Han SQ, Fu G \& Hou CC. Effects of drinking water with high iodine concentration on the intelligence of children in Tianjin, China. Journal of Public Health 200931 32-38. (doi:10.1093/pubmed/fdn097)

Received 26 March 2012

Revised version received 8 May 2012

Accepted 22 June 2012 